\title{
THE ANTIBACTERIAL ACTIVITY OF BAWANG DAYAK (ELEUTHERINE BULBOSA (MILL.) URB.) FROM CENTRAL KALIMANTAN AGAINST ACNE-CAUSING BACTERIA
}

\author{
SUSI NOVARYATIIN*, SYAHRIDA DIAN ARDHANY \\ Department of Pharmacy, Faculty of Health Science, Universitas Muhammadiyah Palangkaraya, Palangka Raya, Central Kalimantan, \\ Indonesia. Email: susi_novaryatiin@yahoo.com
}

Received: 10 December 2018, Revised and Accepted: 20 July 2019

\section{ABSTRACT}

Objective: The objective of this research was to investigate the antibacterial activity of bawang dayak from Central Kalimantan against acne-causing bacteria namely Propionibacterium acnes, Staphylococcus epidermidis, and Staphylococcus aureus.

Methods: The preliminary phytochemical constituents were qualitatively analyzed. Antibacterial activity of bawang dayak ethanol extract was performed using disc-diffusion technique, with five variations of concentration of $1.25 \%, 2.5 \%, 5 \%, 10 \%$, and $20 \%$.

Results: Bawang dayak extract contained flavonoids, alkaloids, saponins, and tannins. The inhibition zones of bawang dayak ethanol extract in five various concentrations $(1.25 \%, 2.5 \%, 5 \%, 10 \%$, and $20 \%)$ were $7.0 \pm 1.3 \mathrm{~mm}, 8.5 \pm 0.6 \mathrm{~mm}, 9.9 \pm 0.3 \mathrm{~mm}, 11.2 \pm 0.1 \mathrm{~mm}$, and $11.9 \pm 0.3 \mathrm{~mm}$ against $P$. acnes; $18.8 \pm 3.3 \mathrm{~mm}, 21.9 \pm 3.3 \mathrm{~mm}, 20.8 \pm 0.6 \mathrm{~mm}, 22.0 \pm 0.2 \mathrm{~mm}$, and $23.1 \pm 0.6 \mathrm{~mm}$ against $S$. epidermidis; and $14.3 \pm 3.1 \mathrm{~mm}, 13.5 \pm 0.9 \mathrm{~mm}, 14.7 \pm 1.5 \mathrm{~mm}$, $16.1 \pm 1.0 \mathrm{~mm}$, and $20.1 \pm 0.6 \mathrm{~mm}$ against $S$. aureus, respectively.

Conclusion: This present study showed that bawang dayak ethanol extract was active against all the tested acne-causing bacteria. The highest antibacterial activity was produced by $20 \%$ of bawang dayak ethanol extract against $S$. epidermidis.

Keywords: Antibacterial activity, Eleutherine bulbosa (Mill.) Urb., Acne, Propionibacterium acnes, Staphylococcus epidermidis, Staphylococcus aureus. (c) 2019 The Authors. Published by Innovare Academic Sciences Pvt Ltd. This is an open access article under the CC BY license (http://creativecommons. org/licenses/by/4. 0/) DOI: http://dx.doi.org/10.22159/ijap.2019.v11s5.T0032

\section{INTRODUCTION}

Acne is a disease of the pilosebaceous unit that causes noninflammatory lesions (open and closed comedones), inflammatory lesions (papules, pustules, and nodules), and varying degrees of scarring [1]. Acne is one of the most common and chronic skin infections, affecting almost everyone during his lifetime [2]. Acne occurs mostly during adolescence, namely in girls aged $14-17$ years and boy aged 16-19 years. However, it can also arise at 40 years, and this disease can also persist into adulthood $[3,4]$. In Indonesia, around $95-100 \%$ of young men and $83-$ $85 \%$ of young woman suffer from acne. The prevalence of acne in adult women is around $12 \%$ and $3 \%$ in adult men. In another study, it was found that acne is a skin problem until past adolescence with a higher prevalence of women than men in the age range of 20 years or more [5].

This infection was influenced by several internal and external factors such as androgen-mediated stimulation of sebaceous gland activity, follicular hyperkeratinization, hormonal imbalance, inflammation, and external bacterial infection. Some of the bacteria that cause acne include Propionibacterium acnes, Staphylococcus epidermidis, and Staphylococcus aureus [6,7].

P. acnes is a Gram-positive bacteria and is a normal flora of the skin that plays a role in the formation of acne. P. acnes was involved in the development of inflammatory acne by activating complements and metabolizing sebaceous triglycerides into fatty acids that irritate the follicular wall and surrounding dermis [8]. S. epidermidis is an aerobic Gram-positive bacteria, which is usually involved in superficial skin infections in sebaceous units. These bacteria are known as pus-forming bacteria that trigger inflammation of acne [9]. In addition, colonization of the skin by $S$. aureus, an opportunistic Gram-positive pathogen, can also cause acne, and these bacteria can also cause superficial skin infections such as ulcers and impetigo [10].
Treatment of acne can be done by giving antibiotics such as clindamycin, tetracycline, and erythromycin with the aim of reducing the population of bacteria. It has been reported that acne patients receive clindamycin, tetracyclin, and erythromycin as their treatment tended to cause an increased occurrence of upper respiratory tract infections when compared with acne patients without antibiotic therapy [11]. In addition, the use of antibiotics as the first choice of acne treatment may result in antibiotic resistance due to the evolutionary adaptation of bacteria. Antibiotics have limitations with respect to toxicity and side effects also such as skin drying, headache, and nausea [12]. This condition encourages the development of research to explore antimicrobial agents from herbal resources that may provide valuable leads that can be further developed as anti-acne drugs.

Bawang dayak is one of the traditional medicines that used by the local people of Central Kalimantan Province. Empirically, bawang dayak bulb was known to have properties to treat various diseases such as breast cancer, hypertension, diabetes, cholesterol, acne, ulcers, and colon cancer and to prevent stroke, dysentery, dysuria, and colitis. Active compounds contained in bawang dayak bulb that can provide antibacterial activity include alkaloids, glycosides, flavonoids, phenols, steroids, and tannins [13,14]. The previous study reported that bawang dayak ethanol extract gave minimal inhibitory concentration (MIC) at the concentration of $10 \mathrm{mg} / \mathrm{ml}$ against the bacteria $P$. acnes, S. epidermidis, and $S$. aureus $[15,16]$. The present study was initiated to investigate the antibacterial activity of bawang dayak ethanol extract obtained by percolation method against acne-causing bacteria namely P. acnes, S. epidermidis, and S. aureus.

\section{MATERIALS AND METHODS}

Collection and identification of plant material

Bawang dayak (Eleutherine bulbosa (Mill.) Urb.) were collected from Sei Gohong Village, Bukit Batu Sub-District, Palangka Raya, Central 
Kalimantan, Indonesia. The collected plant material was identified and authenticated by research center for biology of Indonesian Institute of Sciences.

\section{Preparation of plant extract}

The bulb part of bawang dayak was washed thoroughly with tap water, shade dried, powdered using a blender, and stored. Dried powders of bawang dayak were extracted with ethanol $96 \%$ using percolator's apparatus. The advantage of the percolation method was easy and simple, and the risk of impurity is very small because it uses exhaustive extraction at room temperature. The use of $96 \%$ ethanol solvents was due to its universal properties that capable of dissolving almost all types of secondary metabolites that have low molecular weight such as flavonoids, saponins, and alcohol; nontoxic; and safe to use [17]. The extract was concentrated and then subjected to preliminary phytochemical analysis. The percentage yields $(\mathrm{w} / \mathrm{w})$ of the extracts were calculated using the formula below [18]:

(Weight of extract $\div$ Weight of starting plant material) $\times 100 \%$

\section{Phytochemical screening}

The extract was used for preliminary screening of phytochemical constituents such as flavonoids, alkaloids, saponins, tannins, and steroids $[19,20]$.

\section{Preparation of inoculum}

P. acnes, S. epidermidis, and S. aureus were grown in brain heart infusion medium for $24 \mathrm{~h}$ at $37^{\circ} \mathrm{C}$ and then were grown on the blood agar plate for $24 \mathrm{~h}$ at $37^{\circ} \mathrm{C}$.

\section{Determination of antibacterial activity}

Antibacterial activity was performed using disc-diffusion technique, where the discs were impregnated with five variations of concentration of $1.25 \%, 2.5 \%, 5 \%, 10 \%$, and $20 \%$. The McFarland 0.5 standard was prepared and $10 \mathrm{~mL}$ was put into sterile tubes. Bacterial suspension was made by taking bacterial colonies diluted in sterile normal saline and the turbidity adjusted to $1-2 \times 10^{8} \mathrm{CFU} / \mathrm{mL}$ (according to McFarland 0.5 standard). A sterile cotton swab was immersed in a standardized bacterial suspension and was used to evenly inoculate on Mueller-Hinton agar plate. Then, all the discs that have been immersed in bawang dayak ethanol extract were placed on the plates. A clindamycin antibiotic was used as positive controls with concentration variations of $0.2 \%, 0.4 \%$, $0.6 \%, 0.8 \%$, and $1.0 \%$ against $P$. acnes and $0.02 \%, 0.04 \%, 0.06 \%, 0.08 \%$, and $0.10 \%$ against $S$. epidermidis and $S$. aureus. Discs that have been immersed in clindamycin were also placed on the plates. The plates were then incubated for $24 \mathrm{~h}$ at $37^{\circ} \mathrm{C}$. The diameter of the zone of inhibition formed was measured in mm using a caliper. The study was repeated in triplicates for each extract and positive control.

\section{RESULTS AND DISCUSSION}

\section{Yield of the extract}

From the rendement calculation, the extraction of bawang dayak yields of $6.0 \%$. Value yield is related to the number of secondary metabolites that successfully attracted when the extraction processes [18].

\section{Phytochemical screening}

The results of preliminary phytochemical screening of bawang dayak ethanol extract are shown in Table 1.

The results showed that bawang dayak ethanol extract contained flavonoids, alkaloids, saponins, and tannins. The presence of flavonoids, alkaloids, saponins, and tannins in bawang dayak extract can be responsible for the antibacterial properties observed. Alkaloids can inhibit bacterial growth by disrupting the constituent components of peptidoglycan in bacterial cells so that the cell wall layer is not formed intact and causes bacterial cell death [21]. Flavonoids are known to cause damage to the permeability of bacterial cell walls, microsomes, and lysosomes as a result of interactions between flavonoids and bacterial DNA through inhibition which results in the incorporation of non-cross-linked glucan chains into the cell membrane peptidoglycan so that it becomes a weak structure [22]. Tannins can bind to prolinerich proteins and interfere with protein synthesis [23]. Saponin acts as a chemical barrier in the plant defense system to encounter the pathogens. Saponins can cause leakage of certain proteins and enzymes from bacterial cells [24].

\section{Antibacterial activity}

In this study, clindamycin was used as positive controls. Clindamycin was known as one of the antibiotics that used for acne treatment [11]. The diameters of inhibition zones produced by clindamycin with concentration $0.2 \%, 0.4 \%, 0.6 \%, 0.8 \%$, and $1.0 \%$ against $P$. acnes were $23.0 \pm 0.4 \mathrm{~mm}, 25.4 \pm 0.0 \mathrm{~mm}, 29.0 \pm 0.2 \mathrm{~mm}, 29.9 \pm 0.8 \mathrm{~mm}$, and $31.2 \pm 0.1 \mathrm{~mm}$, respectively as presented in Table 2. The diameters of inhibition zones of clindamycin at concentrations of $0.02 \%$, $0.04 \%, 0.06 \%, 0.08 \%$, and $0.10 \%$ against $S$. epidermidis and S. aureus were $31.7 \pm 0.8 \mathrm{~mm}, 35.6 \pm 1.0 \mathrm{~mm}, 37.1 \pm 1.6 \mathrm{~mm}, 37.7 \pm 0.1 \mathrm{~mm}$, and $39.7 \pm 0.4 \mathrm{~mm}$ and $27.0 \pm 0.5 \mathrm{~mm}, 29.0 \pm 0.8 \mathrm{~mm}, 30.4 \pm 0.4 \mathrm{~mm}$, $30.8 \pm 1.9 \mathrm{~mm}$, and $31.5 \pm 0.9 \mathrm{~mm}$, respectively (Table 2). The diameters of inhibition zones produced by all tested concentrations of clindamycin against all tested bacteria were greater than the diameters of inhibition zones produced by bawang dayak ethanol extract.

Previous studies reported that bawang dayakethanol extract obtained by the soxhletation method was able to inhibit the growth of S. epidermidis in all tested concentrations of $1 \%, 5 \%, 10 \%$, and $15 \%$ [25]. Another previous study also reported that the inhibition zones of bawang dayak ethanol extract against $P$. acnes at concentrations of $5 \%$ and $10 \%$ were $6.1 \pm 1.5 \mathrm{~mm}$ and $8.7 \pm 1.3 \mathrm{~mm}$, respectively [26]. However, this present study showed a better antibacterial activity of bawang dayak ethanol extract against acne-causing bacteria, namely P. acnes, S. epidermidis, and S. aureus.

The antibacterial activity test of the extract against all tested bacteria was done in triplicates. Accordingly, bawang dayak ethanol extract was active against all the tested bacteria, whose inhibition zones were in the range of 7.0 $\pm 1.3-23.1 \pm 0.6 \mathrm{~mm}$ (Fig. 1). The highest antibacterial effect was found for bawang dayak ethanol extract against $S$. epidermidis, with the diameters of inhibition zones at concentrations of $1.25 \%, 2.5 \%$, $5 \%, 10 \%$, and $20 \%$ being $18.8 \pm 3.3 \mathrm{~mm}, 21.9 \pm 3.3 \mathrm{~mm}, 20.8 \pm 0.6 \mathrm{~mm}$, $22.0 \pm 0.2 \mathrm{~mm}$, and $23.1 \pm 0.6 \mathrm{~mm}$, respectively. The diameters of inhibition zones produced in concentrations of $1.25 \%, 2.5 \%, 5 \%$, $10 \%$, and $20 \%$ against $S$. aureus were $14.3 \pm 3.1 \mathrm{~mm}, 13.5 \pm 0.9 \mathrm{~mm}$, $14.7 \pm 1.5 \mathrm{~mm}, 16.1 \pm 1.0 \mathrm{~mm}$, and $20.1 \pm 0.6 \mathrm{~mm}$, respectively. On the other hand, the diameters of inhibition zones of bawang dayak ethanol

\section{Table 1: Results of phytochemical screening of bawang dayak} ethanol extract

\begin{tabular}{ll}
\hline Secondary metabolites & Bawang dayak ethanol extract \\
\hline Flavonoids & + \\
Alkaloids & + \\
Saponins & + \\
Tannins & + \\
Steroids & - \\
\hline
\end{tabular}

+: Detected, -: Not detected

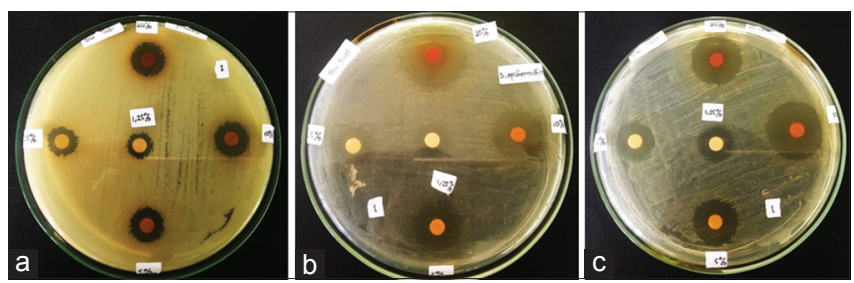

Fig. 1: Antibacterial activity of bawang dayak ethanol extract against Propionibacterium acnes (a) Staphylococcus epidermidis (b) and Staphylococcus aureus (c) 
Table 2: Antibacterial activity of clindamycin against acne-inducing bacteria

\begin{tabular}{|c|c|c|c|c|}
\hline \multirow[t]{2}{*}{ Materials } & \multirow[t]{2}{*}{ Concentration (\%) } & \multicolumn{3}{|c|}{ Inhibition zone diameter $(\mathrm{mm})($ mean $\pm S D ; n=3)$} \\
\hline & & P. acnes & S. epidermidis & S. aureus \\
\hline \multirow[t]{9}{*}{ Clindamycin (positive control) } & 0.02 & - & $31.7 \pm 0.8$ & $27.0 \pm 0.5$ \\
\hline & 0.06 & - & $37.1 \pm 1.6$ & $30.4 \pm 0.4$ \\
\hline & 0.08 & - & $37.7 \pm 0.1$ & $30.8 \pm 1.9$ \\
\hline & 0.10 & - & $39.7 \pm 0.4$ & $31.5 \pm 0.9$ \\
\hline & 0.2 & $23.0 \pm 0.4$ & - & - \\
\hline & 0.4 & $25.4 \pm 0.0$ & - & - \\
\hline & 0.6 & $29.0 \pm 0.2$ & - & - \\
\hline & 0.8 & $29.9 \pm 0.8$ & - & - \\
\hline & 1.0 & $31.2 \pm 0.1$ & - & - \\
\hline
\end{tabular}

-: Not tested, P. acnes: Propionibacterium acnes, S. epidermidis: Staphylococcus epidermidis, S. aureus: Staphylococcus aureus, SD: Standard deviation

Table 3: Antibacterial activity of bawang dayak ethanol extract against acne-inducing bacteria

\begin{tabular}{|c|c|c|c|c|}
\hline \multirow[t]{2}{*}{ Materials } & \multirow[t]{2}{*}{ Concentration (\%) } & \multicolumn{3}{|c|}{ Inhibition zone diameter $(\mathrm{mm})($ mean $\pm S D ; n=3)$} \\
\hline & & P. acnes & S. epidermidis & S. aureus \\
\hline \multirow[t]{5}{*}{ Bawang Dayak ethanol extract } & 1.25 & $7.0 \pm 1.3$ & $18.8 \pm 3.3$ & $14.3 \pm 3.1$ \\
\hline & 2.5 & $8.5 \pm 0.6$ & $21.9 \pm 3.3$ & $13.5 \pm 1.0$ \\
\hline & 5 & $9.9 \pm 0.3$ & $20.8 \pm 0.6$ & $14.7 \pm 1.5$ \\
\hline & 10 & $11.2 \pm 0.1$ & $22.0 \pm 0.2$ & $16.1 \pm 1.0$ \\
\hline & 20 & $11.9 \pm 0.3$ & $23.1 \pm 0.6$ & $20.1 \pm 0.6$ \\
\hline
\end{tabular}

P. acnes: Propionibacterium acnes, S. epidermidis: Staphylococcus epidermidis, S. aureus: Staphylococcus aureus, SD: Standard deviation

extract against $P$. acnes at concentrations of $1.25 \%, 2.5 \%, 5 \%, 10 \%$, and $20 \%$ were $7.0 \pm 1.3 \mathrm{~mm}, 8.5 \pm 0.6 \mathrm{~mm}, 9.9 \pm 0.3 \mathrm{~mm}, 11.2 \pm 0.1 \mathrm{~mm}$, and $11.9 \pm 0.3 \mathrm{~mm}$, respectively (Table 3 ). The antimicrobial activities of extracts can be classified into three levels such as weak activity (inhibition zone lower than $12 \mathrm{~mm}$ ), moderate activity (inhibition zone between 12 and $20 \mathrm{~mm}$ ), and strong activity (inhibition zone higher than $20 \mathrm{~mm}$ ) [27].

\section{CONCLUSION}

The results of this study showed that bawang dayak ethanol extract has potentials to inhibit the growth of acne-causing bacteria. Bawang dayak ethanol extract was active against all the tested bacteria, whose inhibition zones were in the range of $7.0 \pm 1.3-23.1 \pm 0.6 \mathrm{~mm}$. The highest antibacterial activity was produced by $20 \%$ of bawang dayak ethanol extract against $S$. epidermidis, wherein the resulting inhibition zone diameter was $23.1 \pm 0.6 \mathrm{~mm}$. The presence of flavonoids, alkaloids, saponins, and tannins in the extract can be responsible for the antimicrobial properties observed. Further research is needed to obtain MIC and to develop an antibacterial formulation for acne treatment from bawang dayak extract.

\section{ACKNOWLEDGMENT}

The authors would like to express their great appreciation to the Overseas Seminar Assistance Program, Directorate General of Research and Development, Kemenristekdikti of Indonesia (program bantuan seminar luar negeri ditjen penguatan riset dan pengembangan, Kemenristekdikti Indonesia) to facilitate the $20194^{\text {th }}$ International Conference on Pharmacy and Pharmaceutical Science (ICPPS 2019), March 28-30, 2019.

\section{REFERENCES}

1. Tan AU, Schlosser BJ, Paller AS. A review of diagnosis and treatment of acne in adult female patients. Int J Womens Dermatol 2018;4:56-71.

2. Azimi H, Fallah-Tafti M, Khakshur AA, Abdollahi M. A review of phytotherapy of acne vulgaris: Perspective of new pharmacological treatments. Fitoterapia 2012;83:1306-17.

3. Bhate K, Williams HC. Epidemiology of acne vulgaris. Br J Dermatol 2013;168:474-85.

4. Sinha P, Srivastava S, Mishra N, Yadav NP. New perspectives on antiacne plant drugs: Contribution to modern therapeutics. Biomed Res Int 2014;2014:301304.

5. Sudharmono A. Laser Skin Resurfacing. Surabaya: Seminar Perspective of Laser Dermatology; 2008.

6. Coenye T, Peeters E, Nelis HJ. Biofilm formation by Propionibacterium acnes is associated with increased resistance to antimicrobial agents and increased production of putative virulence factors. Res Microbiol 2007;158:386-92.

7. Williams HC, Dellavalle RP, Garner S. Acne vulgaris. Lancet 2012;379:361-72.

8. Zaenglein AL, Pathy AL, Schlosser BJ, Alikhan A, Baldwin HE, Berson DS, et al. Guidelines of care for the management of acne vulgaris. J Am Acad Dermatol 2016;74:945-7.

9. Kumar GS, Jayaveera KN, Kumar CK, Sanjay UP, Swamy BM, Kumar DV. Antimicrobial effects of Indian medicinal plants against acne-inducing bacteria. Trop J Pharm Res 2007;6:717-23.

10. Mostwaledi MH. Superficial skin infection and the use of topical and systemic antibiotics in general practise. S Afr Farm Pract 2011;53:139-42.

11. Margolis DJ, Bowe WP, Hoffstad O, Berlin JA. Antibiotic treatment of acne may be associated with upper respiratory tract infections. Arch Dermatol 2005;141:1132-6.

12. Kumar A, Baboota S, Agarwal S, Ali J, Ahuja A. Treatment of acne with special emphasis on herbal remedies. Expert Rev Dermatol 2008;3:111-22.

13. Galingging RY. Bawang dayak as multifunctional medicinal plants. Res Dev News 2009;15:2-4.

14. Ieyama T, Gunawan-Puteri MD, Kawabata J. A-glucosidase inhibitors from the bulb of Eleutherine americana. Food Chem 2011;128:308-11.

15. Mierza V, Suryanto D, Nasution PM. Phytochemical Screening and Antibacterial Effect Assay of Bawang Sabrang (Eleutherine palmifolia Merr.) Bulbus Ethanol Extract. Proceeding of National Seminars; 2011.

16. Warnida H, Sukawaty Y, Mega M. Stability and activity of bawang tiwai (Eleutherine americana (Mill.) Urb.) bulbus gel extract as anti acne. J Ilmiah Manuntung 2015;1:94-9.

17. Arifianti L, Oktarina RD, Kusumawati I. Effect of solvent extraction type on sinesetin levels in Orthosiphon stamineus Benth. E J Plant Husada 2014;2:3.

18. Kusuma SA, Mita SR, Firdayani I, Mustarichie R. Study on the antibacterial activity of fruit extracts of klutuk banana (Musa balbisiana Colla) against Shigella dysenteriae ATCC 13313. Asian J Pharm Clin Res 2017;10:220-3.

19. Mojab F, Kamalinejad M, Ghaderi N, Vahidipour HR. Phytochemical screening of some species of Iranian plants. Iran J Pharm Res 
$2003 ; 2: 77-82$

20. Ghosal M, Mandal P. Phytochemical screening and antioxidant activities of two selected 'BIHI' fruits used as vegetables in Darjeeling himalaya. Int J Pharm Pharm Sci 2012;4:567-74.

21. Darsana I, Besung I, Mahatmi H. Potential of binahong leaf (Anredera cordifolia (Tenore) steenis) to inhibit the growth of Eschericia coli in vitro. Indones Med Vet 2012;1:337-51.

22. Sulastrianah S, Imran I, Fitria ES. The inhibitory test of sirsak leaf extract (Annona muricata L.) and sirih leaf extract (Piper betle L.) against Eschericia coli. J Medula 2014;1:76-84.

23. Shimada T. Salivary proteins as a defense against dietary tannins. J Chem Ecol 2006;32:1149-63.

24. Ravi L, Manasvi V, Praveena LB. Antibacterial and antioxidant activity of saponin from Abutilon indicum leaves. Asian J Pharm Clin Res 2016;9:344-7

25. Novaryatiin S, Pratiwi AM, Ardhany SD. The inhibitory test of bawang dayak (Eleutherine bulbosa (Mill.) Urb.) against Staphylococcus epidermidis. J Anterior 2018;18:92-7.

26. Novaryatiin S. Phytochemical Screening and Antibacterial Activity of Bawang Dayak (Eleutherine sp.) and Hati Tanah (Angiopteris sp.) and Their Combination Against Propionibacterium acnes. Int J App Pharm 2019;11:11-3

27. Shahbazi Y. Antibacterial and antioxidant properties of methanolic extracts of apple (Malus pumila), grape (Vitis vinifera), pomegranate (Punica granatum L.), and common fig (Ficus carica L.) fruits. Pharm Sci 2017;23:308-15 